\title{
Öğretmenlerin Öğrenme Güçlüğü Yaşayan Öğrencilere Yönelik Yeterlikleri, Öz Yeterlik Kaynakları ve Pozitif Öğretmenlik Becerileri Arasındaki İlişki
}

\author{
Oğuz Emrea, ${ }^{a}$, Ayşegül Ulutaşc, Ramazan İnci ${ }^{d}$, Burcu Coşanaye, Mine Ayanoğlu ${ }^{\mathrm{f}}$, Cihangir Kaçmaz \\ Mehmet Akif Kay
}

Özet

Anahtar Kelimeler

Günümüzde öğrenme güçlüğü yaşayan çocukların eğitimi, toplumsal bir sorun haline gelmiştir. Türkiye'de de bu konu ile ilgili yapılan araştırmalar sınırlı düzeydedir. Bu çalışmada, öğretmenlerin öğrenme güçlüğü yaşayan öğrencilere yönelik yeterlikleri, öz yeterlik kaynakları ve pozitif öğretmenlik becerileri arasındaki ilişkisinin incelenmesi amaçlanmaktadır. Nicel araştırma olarak tasarlanan araştırmanın çalışma grubunu, tesadüfen seçilen 25 resmi ilkokul ve 10 özel ilkokulda görev yapan toplam 317 öğretmen oluşturmaktadır. Veri toplama aracı olarak Öğrenme Güçlüğü Yaşayan Öğrencilere Yönelik Öğretmen Yeterlilikleri Ölçeği, Pozitif Öğretmen Ölçeği ve Öz Yeterlik Kaynakları Ölçeği kullanılmıştır. Verilerin çözümlenmesinde betimleyici istatistikler ve Pearson Korelasyon katsayıları kullanılmıştır. Sonuçta; öğretmenlerin derste akış yaşatmak ile dikkate alma, güdüleme, derse odaklanma, dikkat toplama ve olumlu tutum arasında pozitif yönde, orta düzeyde ve anlamlı bir ilişki ortaya çıkmıştır.
Öğrenme güçlüğü
Öz yeterlik
Pozitif öğretmenlik
Öğretmen

\section{Makale Hakkında}

Geliş Tarihi: 12.10.2019

Kabul Tarihi: 13.03.2020

Doi: $10.18026 /$ cbayarsos.632453

\section{The Relationship between Competencies of Teachers Towards Students with Learning Disabilities, Their Resources of Self-Efficacy and Positive Teaching Skills}

\begin{abstract}
Today, the education of children with learning disabilities has become a social issue. There are few studies on this subject in Turkey. This study aims to investigate the relationship between competencies of teachers towards students with learning disabilities, their self-efficacy resources of and positive teaching skills. The study group of the research, which is designed as quantitative research, consists of 317 teachers working in 25 official primary schools and 10 private primary schools. The Teacher Competencies towards Students with Learning Disabilities Scale, the Positive Teacher Scale and SelfEfficacy Resources Scale were used for data collection. Descriptive statistics and Pearson correlation coefficients were used to analyze the data. As a result, a positive, moderate and significant relationship was found between the teachers' positive attitudes and creating a flow during the course, consideration, motivation, focus on the lesson, and attention gathering.
\end{abstract}

Keywords

Learning disability

Self-efficacy

Positive teaching

Teacher

About Article

Received: 12.10 .2019

Accepted: 13.03.2020

Doi: $10.18026 /$ cbayarsos.632453

\footnotetext{
a İletişim Yazarı: oguz.emre@inonu.edu.tr

b Dr. Öğr. Üyesi, İnönü Üniversitesi, Sağl1k Bilimleri Fakültesi, Çocuk Gelişimi Bölümü, Malatya, ORCID: 0000-0001-6810-3151

c Doç. Dr., İnönü Üniversitesi, Sağlık Bilimleri Fakültesi, Çocuk Gelişimi Bölümü, Malatya, ORCID: 0000-0002-6497-6534

d Arş. Gör., Batman Üniversitesi, Sağlık Yüksekokulu, Hemşirelik Bölümü, Batman, ORCID: 0000-0002-6855-4574

e Öğr. Gör., Muş Alparslan Üniversitesi, Sağlık Hizmetleri Meslek Yüksekokulu, Çocuk Gelişimi Programı, Muş, ORCID: 0000-0002-8337-3851

f Öğr. Gör., Mardin Artuklu Üniversitesi, Sağlık Hizmetleri Meslek Yüksekokulu, Çocuk Gelişimi Programı, Mardin, ORCID: 0000-0002-5602-4752

g Öğr. Gör., Bingöl Üniversitesi, Genç Meslek Yüksekokulu, Çocuk Gelişimi Programı, Bingöl, ORCID: 0000-0003-0649-5254

h Öğr. Gör., İnönü Üniversitesi, Sağlık Hizmetleri Meslek Yüksekokulu, Çocuk Gelişimi Programı, Malatya, ORCID: 0000-0002-7996-9310
} 


\section{Giriş}

İlk kez 1962 yılında Samuel Kirk tarafından dil, konuşma, okuma ve diğer iletişim becerilerinde gelişimsel bozuklukları olan bir grup çocuğu tanımlamak için kullanılmaya başlanan öğrenme güçlüğü terimi, günümüzde özel eğitime ihtiyaç duyan bireyler arasında en büyük dilimi oluşturan grubu nitelemektedir (Cortiella ve Horowitz 2014; Flanagan, Ortiz ve Alfonso, 2011; Kirk ve Bateman, 1962; Pesova, Sivevska ve Runcevac, 2014). Uluslararası kaynaklara bakıldığında öğrenme güçlüğü terimi, okul çağındaki çocuklarda düşünme, dinleme, okuma-yazma, konuşma, sonuca ulaşma veya matematiksel işlem yapma sürecinde karşılaşılabilen genel zorluklar olarak belirtilmektedir (Fletcher, Lyon, Fuchs ve Barnes, 2007; Jena, 2013; Şahin ve Çakır, 2018; U.S. Department of Education, 2014; Zuriff, 2000). Yavuzer (2000) ise, öğrenme güçlüğünü tanımlarken bireyin okuma, yazma, akademik olarak idrak etme, telaffuz etme, mantık yürütme gibi kabiliyete sahip olamaması ve bunları kullanmakta zorluk çekmesi ifadelerini kullanmıştır. Genel olarak bu zorluk bireyin, bilimi işleme süreci ve bilim öğrenme yetenekleri ile ilgili bir problem ile birlikte, kendi kendini idare etme ve sosyal ilişki kurmada güçlük yaşamak olarak ifade etmektedir. Öğrenme güçlüğü yaşayan öğrenciler yazma, okuma, işlem yapma vb. gibi konu alanlarında başarılı olmak için gereken bilgi, beceri, irade ve öz düzenleme geliştirme sürecinde başarısız olmaktadır. Bu başarısızlık öğrencilerde özgüven eksikliği, sosyal dışlanma, okul derslerinde başarısızlık gibi olumsuz durumları da beraberinde getirmektedir (Grünke ve Cavendish, 2016).

Öğrenme güçlüğü, farklı düzeylerde ve farklı öğrenme alanlarında meydana gelebilmektedir. Öğrencilerin okullarda yaşadığı öğrenme güçlükleri, eğitim sürecinde uygulanan geleneksel eğitim metotlarının eksiklerinden kaynaklandığı ifade edilmektedir. Sınıf ortamında öğrenme güçlüğüne sahip olan öğrencilerin bu sorunlarının eğitim sürecine dâhil olabilecek modern ve çoklu ortam materyalleriyle giderilebileceği düşünülmektedir. Özellikle öğrencilerin okumayazma alanında yaşadığı öğrenme güçlüğü akademik başarılarını büyük bir ölçüde etkilemektedir. Ülkemizde ilkokula devam eden çocukların okuma yazma güçlüğü yaşamaları ve öğrenme sürecinde gecikmelerinin görülmesi öğrencilerin ileriki dönemlerde akademik anlamda zorluk yaşamalarına neden olmaktadır (Şahin ve Çakır, 2018). DSM V'te (2013) öğrenme güçlüğü "özel öğrenme güçlükleri” adı altında üç alt başlıkta açıklanmıştır. Bunlar; okuma güçlüğü (disleksi), yazma güçlüğü (disgrafi) ve matematik güçlüğü (diskaluli)'dür. Sessiz okuma yaparken okuduğunu anlamada zorluk yaşama, doğru bir şekilde ve hızda okuyamama, sesli okuma yaparken seslerin doğru telaffuz edememe ve heceleme yaparken zorluk yaşama olarak ifade edilen okuma güçlüğü yani disleksi olarak belirtilmektedir (Morrison, 2016). Dislektik bireylerin okumada gösterdikleri performansların, zekâ düzeyi, yaş ve eğitim faktörleri dikkate alındığında normal gelişim gösteren bireylere göre düşük olduğu saptanmıştır (İşeri ve Akın-Sarı, 2011). Sayısal ifadeleri ve sembolleri anlama, sayı sayma, dört işleme yönelik soruları çözme, sayı sayma, çarpım tablosunu öğrenme konusunda yaşanan güçlükler ise diskalkuli olarak ifade edilmektedir. Bu bireyler, sayısal problemleri çözme konusunda zorluklar yaşamaktadır bu da akademik başarılarını olumsuz etkilemektedir (Olkun, Akkurt-Denizli ve Göçer-Şahin, 2015). Yazarken noktalama işaretleri, dil bilgisi ve heceleme gibi konularda yaşanan zorluklar disgrafi olarak adlandırılmaktadır (İlker ve Melekoğlu, 2017).

Öğrenme güçlüğü yaşayan bireyler, tutum ve sosyal ilişki gibi konularda da zorluklarla karşılaşmaktadırlar. Özellikle okul çağı çocuklarının yaşadığı bu zorluklar nedeniyle sinirli, dikkatsiz, içe kapanık, hiperaktif, oto kontrolsüz, sorumluluk almaya isteksiz, dağınık ve 
öfkeli olma gibi problem davranışlar sergilediği öğretmenleri tarafından saptanmıştır (Mc Leod, 1993). Toplumun niteliğinin ancak eğitimin kalitesi ile artacağı bilinmekle birlikte bu süreçte en önemli rolü öğretmenler üstlenmektedir. Eğitim sürecinin en önemli öğelerinden olan öğretmen, öğrenci ile devamlı iletişim içinde olan, güncellenen eğitim programlarını takip eden ve uygulayan, eğitim öğretim sürecini koordine eden ve yorumlayan kişidir. Eğitimciler, öğrencileri motive ederek öğrenme sürecini kolaylaştırmakta, öğrenme sürecini daha hızlı bir hale getirerek, bireysel olgunluğa ve kendi yeteneklerine olan güvenleri ile birlikte öğrenme ortamının ve öğrencinin okul başarısını olumlu bir şekilde etkilemektedir (Bandura, 1993).

Eğitim kurumlarında öğrencilerle vakit geçiren, eğitsel etkinliklere katılım gösteren öğretmenlerin, bu durum üzerinde ilgi ve alakalarını yoğunlaştırmaları, gerek öğrenme güçlüğü çeken öğrencilerin tanınmasında gerek bu öğrencilere yönelik adımların tespitinde gereklidir (Korkut, Keskin ve Can, 2016). Okul ortamında öğretmenlerin; öğrencilerin okul hayatını ve sosyal yaşantılarını, etkileyebileceklerinin bilincinde olmaları, yaptıkları işten daha kararlı ve güvenli olarak ilerlemeleri ve yaptıkları işlerin ayrıca sergiledikleri tutumlarda da model olduklarını bilmeleri gerekmektedir (Enderlin-Lampe, 2002). Öğretmenler, öğrencilerinin performanslarını çeşitli yollar doğrultusunda gözlemleyerek öğrencinin öğrenmeye hazır olup olmadığını anlar, eğitim planını ders faaliyetlerini belirler ve öğrencilerin öğrenme sürecinde yaşadıkları güçlükleri ortaya çıararak, öğrencinin okul yaşantısı ve psiko-sosyal gelişim ile ilgili destek verir. Bu süreç değerlendirme aşamasında önemli bir nokta olarak karşımıza çıkmaktadır (Demirtaşlı, 2007). Öğretme yeteneği konusunda kendine güvenen ve öğrencilerinin performansı ile ilgili umudu yüksek olan öğretmenlerin derse hazırlanmak için daha fazla zaman harcayıp eğitim ve öğretime karşı daha olumlu davranışlar sergiledikleri ve ders anlatımında yardımcı materyal olarak teknolojiyi ve güncel yenilikleri takip ederek bunları eğitim ortamına taşıdıklarını göstermektedir (Albion, 1999; Ginns, Tulip, Waters ve Lucas, 1995; Tosun, 2000).

Öğretmenlerin çocukları nitelikli bir şekilde eğitebilme hissine sahip olması ancak öğretmenin öz yeterlik algısının yerleşmesi ile mümkündür. Sosyal Öğrenme Kuramı içerisinde yer alan öz yeterlik kavramını Bandura, (1997) "bireyin bir işi yapmak için gerekli etkinlikleri düzenleyip başarılı bir biçimde yapma becerisine sahip olduğuna dair öğretisi" olarak tanımlamaktadır. Başka bir ifadeyle öz yeterlik, bireyin var olan görevlerini tamamlamak için sahip olduğu olanaklarına güvendiği yeteneklerdir (Galpin, Senders, Turner ve Venter, 2003). Güçlü öz-yetkinlik inancı olan öğretmenlerin uygun teknikler kullandıklarında ve biraz da ilave çaba gösterdiklerinde en zor öğrencilerin bile öğrenebildiklerini, sınıfta akademik etkinliklere daha çok vakit ayırdıklarını, güçlük yaşayan öğrencilerin başarılı olabilmeleri için destek sağladıklarını ve onların akademik gelişimlerini başarı ile taçlandırmak için daha iyi ders planları hazırlayıp uyguladıklarını, öğrencilerini tartışmaya dâhil etmede kabiliyetli olduklarını göstermektedir (Bandura, 1994).

Öğretmen özelliklerine yönelik yapılan atıflara bakıldığında; usta öğretmen, etkili öğretmen, iletişimi güçlü öğretmen, sevilen öğretmen, yetkin, iyi, yetersiz, yetkin ve sevilmeyen öğretmen gibi özellikler literatürde belirtilmektedir (Grieve, 2010; Helterbran, 2008; Montalvo ve ark., 2007; Thibodeau ve Hillman, 2003). Eryılmaz (2014) ise, öğretmenleri üç grupta incelemiştir bunlar; nötr, sevilen ve sevilmeyen öğretmenlerdir. Bu konu üzerinde yaptığ sonraki çalışmalarda, öğrencilerinin mutluluklarını ve iyi oluş düzeylerini yükseltebilen, onların pozitif durumlarını arttıran öğretmenleri "pozitif öğretmen" olarak ifade etmiştir. 


\section{Öğretmenlerin Öğrenme Güçlüğü Yaşayan Öğrencilere Yönelik Yeterlikleri, Öz Yeterlik Kaynakları ve Pozitif Öğretmenlik Becerileri Arasındaki İlişki}

Yapılan çalışmalara göre bu özelliklere sahip pozitif öğretmenler aynı zamanda dışa dönük, sınıf içerisinde ders ortamındaki akışa öğrencileri aktif olarak dahil etme, öğrencilerle kurduğu ilişkilerde pozitif bir tutum benimseme ve çocukların anlama düzeyini arttırmak için konuları somutlaştırarak ifade etme gibi özelliklere de sahiptir (Eryılmaz, 2014; Eryılmaz, 2017; Eryılmaz ve Bek, 2018; Özbağır, 2019). Bu tür öğretmenlerin öğrenme güçlüğü yaşayan öğrencilerle de pozitif ilişki kuracağı ve öğrenme sürecinde bu öğrencilerin öğrenme becerilerin artması için gerekli olan yöntem, materyal ve teknolojik araçları kullanacağı düşünülmektedir.

Öğrenme güçlüğü yaşayan bireyler, özel gereksinime ihtiyaç duyan bireyler arasında en büyük dilimi oluşturmaktadır, Ancak, bu grupta yer alan öğrencilere eğitim sürecinde yeterli desteğin sağlanmadığı ve öğrencilerin akademik ortamda zorluk yaşadığı bilinmektedir. Bundan dolayı, bu araştırmanın amacı sınıf öğretmenlerinin öğrenme güçlüğü yeterliliklerinin öz yeterlik kaynakları ve pozitif olma durumları ile ilişkisinin incelenmesidir. Bu ana problemden hareketle aşağıdaki sorulara yanıt aranmıştır;

1. Sınıf öğretmenlerinin öğrenme güçlüğü yeterlilikleri öz yeterlik kaynaklarını yordamakta midir?

2. Sınıf öğretmenlerinin öz yeterlik kaynakları pozitif olma durumlarını yordamakta midir?

3. Sınıf öğretmenlerinin öğrenme güçlüğü yeterlilikleri, öz yeterlik kaynakları aracılığıyla pozitif olma durumlarını yordamakta mıdır?

\section{Yöntem}

\section{Araştırma Modeli}

$\mathrm{Bu}$ araştırma, ilişkisel tarama modelinde desenlenmiş olup betimsel niteliktedir. Değişkenler arasındaki korelasyonu belirlemek için örneklemin puanları göz önünde bulundurularak yapılan istatistiksel karşılaştırmalardır (Tekbıyık, 2014).

\section{Çalışma Grubu}

Araştırmanın çalışma grubu, 2018-2019 eğitim-öğretim yılında tesadüfen seçilen Muş, Malatya, Batman, Mardin ve Bingöl illerinde MEB'e bağlı 25 resmi ilkokul ve 10 özel ilkokulda görev yapan toplam 317 öğretmenden oluşturmaktadır. Aşağıdaki tabloda, "kişisel özelliklere ait genel tanımlayıc istatistikler" verilmiştir. Buna göre; tabloda tüm özelliklerin genel dağılımları (sayı ve yüzde) yer almaktadır. Öğretmenlerin \%52.6’sı erkektir. \%43,5'i 31-40 yaş aralığındadır. \%93,5'i lisans mezunudur. \%30,0'1 1-5 yıl mesleki kıdeme sahiptir. \%98,3'ü kamuda çalışmaktadır. \% 77,0'si kentsel yerleşimde yaşamaktadır. Öğretmenlerin \%82,6'sının öğrenme güçlüğüne sahip olan yakını bulunmamaktadır. \%60,4'ünün öğrenme güçlüğüne sahip öğrencisi bulunmaktadır. Öğretmenlerin \%61,7'si sınıfta öğrenme güçlügü olan öğrencilerin destek özel eğitimi aldıklarını belirtmiştir. Öğretmenlerin \%50,9'u öğrenme güçlüğü ile ilgili hizmet içi eğitim aldıklarını belirtmiştir. \%63,0'ü öğrenme güçlügü ile ilgili ders almıştır. Öğretmenlerin \%67,0'sinin öğrenme güçlüğü ile ilgili bilgi düzeylerinin yeterli olmadığını belirtmiştir. 
Tablo 1. Kişisel özelliklere ait genel tanımlayıcı istatistikler

\begin{tabular}{|c|c|c|c|}
\hline & & $\mathrm{N}$ & $\%$ \\
\hline \multirow{2}{*}{ Cinsiyet } & Kadın & 109 & $47,4 \%$ \\
\hline & Erkek & 121 & $52,6 \%$ \\
\hline \multirow{4}{*}{ Yaş } & $20-30$ & 68 & $29,6 \%$ \\
\hline & $31-40$ & 100 & $43,5 \%$ \\
\hline & $41-50$ & 52 & $22,6 \%$ \\
\hline & 51 ve üzeri & 10 & $4,3 \%$ \\
\hline \multirow{4}{*}{ Öğrenim durumu } & Lisans & 215 & $93,5 \%$ \\
\hline & Yüksek Lisans & 15 & $6,5 \%$ \\
\hline & Doktora & 0 & $0,0 \%$ \\
\hline & Lisans tamamlama & 0 & $0,0 \%$ \\
\hline \multirow{6}{*}{ Hizmet yılı } & $1-5$ y1l & 69 & $30,0 \%$ \\
\hline & 6-10 yıl & 38 & $16,5 \%$ \\
\hline & $11-15$ y1l & 62 & $27,0 \%$ \\
\hline & $16-20 \mathrm{y} 1 \mathrm{l}$ & 28 & $12,2 \%$ \\
\hline & $21-25$ y1l & 22 & $9,6 \%$ \\
\hline & 25 yıl ve üzeri & 11 & $4,8 \%$ \\
\hline \multirow{2}{*}{ Çalışılan sektör } & Kamu (MEB) & 226 & $98,3 \%$ \\
\hline & Özel Kurum (MEB) & 4 & $1,7 \%$ \\
\hline \multirow{2}{*}{ Çalışılan yerleşim yeri } & Kirsal & 53 & $23,0 \%$ \\
\hline & Kentsel & 177 & $77,0 \%$ \\
\hline \multirow{2}{*}{ ÖG sahip yakının olup olmadığ1 } & Evet & 40 & $17,4 \%$ \\
\hline & Hayır & 190 & $82,6 \%$ \\
\hline \multirow{2}{*}{ Sınıfta ÖG sahip öğrenci var mı? } & Evet & 139 & $60,4 \%$ \\
\hline & Hayır & 91 & $39,6 \%$ \\
\hline \multirow{2}{*}{$\begin{array}{l}\text { Sınıfta ÖÖG sahip öğrencinin } \\
\text { eğitim görme durumu }\end{array}$} & Evet & 140 & $61,7 \%$ \\
\hline & Hayır & 87 & $38,3 \%$ \\
\hline \multirow{2}{*}{ ÖG ilgili hizmetiçi eğitime katılma } & Evet & 117 & $50,9 \%$ \\
\hline & Hayır & 113 & $49,1 \%$ \\
\hline \multirow{2}{*}{ ÖG ile ilgili ders alma } & Evet & 145 & $63,0 \%$ \\
\hline & Hayır & 85 & $37,0 \%$ \\
\hline \multirow{2}{*}{ ÖG ile ilgili bilgi düzeyiniz yeterli mi? } & Evet & 76 & $33,0 \%$ \\
\hline & Hayır & 154 & $67,0 \%$ \\
\hline
\end{tabular}

\section{Veri Toplama Araçları}

Öğretmen Bilgi Formu: Araştırmacılar tarafından geliştirilen bu formda, öğretmenlerin; cinsiyeti, yaşı, öğrenim durumu, hizmet yılı, çalıştıkları sektör, çalıştıkları yerleşim alanı, öğrenme güçlüğü olan bir yakınının olup olmadığı, sınıfında öğrenme güçlügüune sahip öğrencinin olup olmadığı, öğrenme güçlüğü konusunda hizmet içi eğitim alıp almaması, eğitim sırasında öğrenme güçlüğü ile ilgili ders alıp almama durumu, öğrenme güçlüğü konusunda bilgi düzeyini yeterli bulup bulmadığını araştıran maddeler bulunmaktadır. Hazırlanan form, pilot uygulama olarak 10 öğretmenle gerçekleştirilmiş, formda yer alan sorulardan uygun ve açık olmayan ifadeler değiştirilerek, forma son şekli verilmiştir.

Pozitif Öğretmen Ölçeği: Eryılmaz ve Bek (2017) tarafından geliştirilen ölçek öğretmenlerin kendi bakış açılarından yanıtlanan bir ölçektir. Ölçek, 21 maddeden oluşan beş basamaklı 


\section{Öğretmenlerin Öğrenme Güçlüğü Yaşayan Öğrencilere Yönelik Yeterlikleri, Öz Yeterlik Kaynakları ve Pozitif Öğretmenlik Becerileri Arasındaki İlişki}

likert tipinde bir ölçek olmakla birlikte maddeler "1=Hiç, 2=Çok Az, 3=Biraz, 4= Çoğunlukla, 5=Çok Fazla" olarak cevaplandırılmaktadır. Geçerlik ve güvenirlik çalışması 448 öğretmene uygulanmış ve bu çalışma sonucunda açıklayıcı faktör analizi yapılmış ve 20 maddenin oluşturduğu 5 alt boyut ortaya çıkmıştır. Bunlar; "dışa dönük kişilik özelliğine sahip olmak", "konuyu somutlaştırmak", "öğrenci ile pozitif ilişki kurmak”, "öğrenciyi derse katmak" ve "derste akış yaşatmak"tır. Toplam puan üzerinden değerlendirme yapılan bu araştırmada bu faktörler toplam varyansın \% 63.230'unu açıklamıştır. Ölçeğin güvenirliği, Cronbach Alpha tekniği ile analiz edilmiş ve güvenirlik değeri 0.89 olarak bulunmuştur. Doğrulayıcı faktör analizinin yapılmasıyla ölçeğin uygulandığı gruba uyum sağladığı da görülmüştür (Eryılmaz ve Bek, 2017).

Öz Yeterlik Kaynakları Ölçeği: Ölçek ilk olarak Kieffer ve Henson (2000) tarafından öğretmenler için geliştirilen ölçek, Türkçe'ye Çapa-Aydın, Uzuntiryaki-Kondakçı, Temli ve Tarkın (2013) tarafından uyarlanmıştır. Ölçek yedili derecelendirme; "Kesinlikle doğru değil (1)”, “Genellikle doğru değil (2)”, “Bazen doğru (3)”, “Ara sıra doğru (4)”, “Çoğunlukla doğru (5)”, “Genellikle doğru (6)", “Her zaman doğru (7)” ile cevaplanan 27 madde ve 4 alt boyuttan oluşmaktadır. Ölçeğin alt boyutları ve her bir alt boyutun güvenirlik katsayıları ise, "performans başarıları (.75)", "dolaylı yaşantılar (.78)", "sözel ikna (.76)" ve "fizyolojik ve duygusal durumlar (.75)" olarak bulunmuştur.

Öğrenme Güçlüğü Yaşayan Öğrencilere Yönelik Öğretmen Yeterlilikleri Ölçeği: Keskin, Korkut ve Can (2016) tarafından geliştirilen ölçek, ilk olarak 55 madde olarak planlanmıştır. Ölçeğin taslak hali ortaokulda görevine devam eden 50 öğretmene uygulanmıştır. Öğretmenlerden elde edilen veriler üzerinde yapılan istatiksel işlemlerin ardından faktör yükü düşük olan, farklı alt boyutları kapsayan ve öğretmenler tarafından anlaşılmayan maddeler ölçekten çıkarılarak ölçeğe son hali verilmiştir. Beşli likert tipinde oluşturulan ölçeğin cevap dereceleri; "Hiç Katılmıyorum (1)”, “Az Katılıyorum (2)”, “Orta Düzeyde Katılıyorum (3)", "Çok Katılıyorum (4)" ve “Tamamen Katıliyorum (5)" şeklinde sınıflandırılmıştır. Ölçeğin son hali 22 madde ve 5 alt boyuttan oluşmaktadır. Ölçeğin alt boyutları ise; 'Dikkate alma (5 madde)', ‘Güdüleme (5 madde)', 'Derse odaklama (4 madde)', 'Dikkat toplama (4 madde)' ve 'Olumlu tutum (4 madde)' olarak belirlenmiştir. Ölçeğin son hali 228 öğretmene uygulanmış ve faktör analizi neticesinde Cronbach Alpha iç tutarlık katsayısı .901 olarak belirlenmiştir.

\section{Verilerin Analizi}

Öğretmenlerin öz yeterlik kaynakları ile öğrenme güçlüğü olan öğrencilere yönelik yeterlikleri arasındaki ilişkilerin pozitif öğretmenlik becerisi aracılığıyla incelenmesi amacıyla yapılan bu çalışmada sürekli değişkenler için tanımlayıcı istatistikler; ortalama, standart sapma, minimum ve maksimum; kategorik değişkenler ise sayı ve yüzde değerleri kullanılmıştır. Ölçekler arasındaki ilişkiyi test etmek için Pearson Korelasyon katsayıları hesaplanmıştır. İstatistiksel anlamlılık $(\alpha) \% 5$ olarak belirlenmiş ve veri çözümlemesi için SPSS (IBM SPSS for Windows, Ver.24) programı kullanılmıştır. Bu araştırmada Öz Yeterlik Kaynakları Ölçeğine ait Cronbach's Alpha değeri 0,905 (\%90,5), Öğrenme Güçlüğü Yaşayan Öğrencilere Yönelik Öğretmen Yeterlilikleri Ölçeğine ait Cronbach's Alpha değeri 0,939 (\%93,9), Pozitif Öğretmen Ölçeğine ait Cronbach's Alpha değeri 0,906 (\%90,6) bulunmuştur. Üç ölçeğe ait Cronbach's Alpha değerinin \%80'nin üzerinde çıkması ölçek maddelerinin güvenirliğinin yüksek olduğunu göstermektedir. 
Tablo 2. Ölçek alt boyutları puanlarına ait genel tanımlayıcı istatistikler

\begin{tabular}{l|c|c|c|c}
\hline & Mean & Std. Dev. & Min. & Max. \\
\hline ÖY Performans başarıları & 44,55 & 6,55 & 12,00 & 56,00 \\
\hline ÖY Dolaylı yaşantılar & 35,08 & 6,97 & 12,00 & 49,00 \\
\hline ÖY Sözel ikna & 26,30 & 5,29 & 6,00 & 35,00 \\
\hline ÖY Fizyolojik ve duygusal durumlar & 23,56 & 7,97 & 8,00 & 40,00 \\
\hline ÖG Dikkate alma & 17,17 & 2,48 & 7,00 & 20,00 \\
\hline ÖG Güdüleme & 22,36 & 2,41 & 12,00 & 25,00 \\
\hline ÖG Derse Odaklama & 17,47 & 2,45 & 7,00 & 20,00 \\
\hline ÖG Dikkat toplama & 17,79 & 2,15 & 6,00 & 20,00 \\
\hline ÖG Olumlu Tutum & 17,52 & 2,45 & 8,00 & 20,00 \\
\hline PÖÖ Derste akış yaşatmak & 13,06 & 1,31 & 8,00 & 15,00 \\
\hline PÖÖ Dişa dönük kişilik özelliğine sahip olmak & 21,05 & 3,01 & 11,00 & 25,00 \\
\hline PÖÖ Konuyu somutlaştırarak anlatmak & 16,95 & 2,39 & 8,00 & 20,00 \\
\hline PÖÖ Öğrenciyi derse katmak & 16,99 & 2,40 & 5,00 & 20,00 \\
\hline PÖÖ Öğrenci ile pozitif ilişki kurmak & 22,79 & 2,31 & 13,00 & 25,00 \\
\hline
\end{tabular}

Yukarıdaki tabloda, "Ölçek alt boyutları puanlarına ait genel tanımlayıcı istatistikler" verilmiştir. Buna göre; ölçekler alt boyutlarının ortalama ve standart sapma değerleri tabloda özetlenmiştir.

Tablo 3. Ölçek alt boyutları arasındaki korelasyon katsayıları

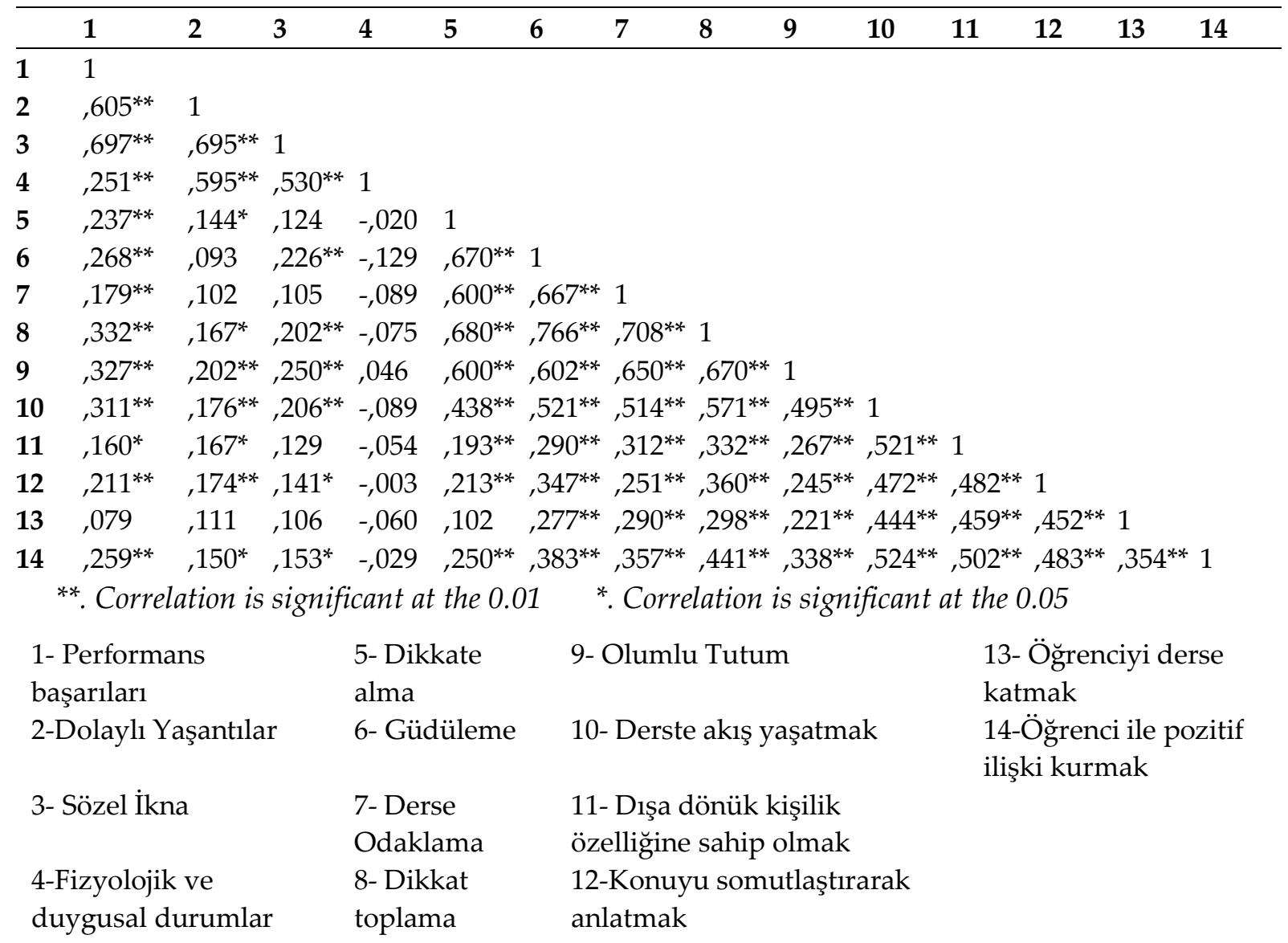




\section{Öğretmenlerin Öğrenme Güçlüğü Yaşayan Öğrencilere Yönelik Yeterlikleri, Öz Yeterlik Kaynakları ve Pozitif Öğretmenlik Becerileri Arasındaki İlişki}

Tablo 3 incelendiğinde, ölçek alt boyutları arası korelasyon katsayıları verilmiştir.

- Dikkat toplama, olumlu tutum ve derste akış yaşatmak ile performans başarıları arasında pozitif yönde, orta düzeyde ve anlamlı $(p<0,05)$ bir ilişki saptanmıştır.

- Derste akış yaşatmak ile dikkate alma, güdüleme, derse odaklanma, dikkat toplama ve olumlu tutum arasında pozitif yönde, orta düzeyde ve anlamlı $(p<0,05)$ bir ilişki ortaya çımıştır.

- Dişa dönük kişilik özelliğine sahip olmak ile derse odaklanma ve dikkat toplama arasında pozitif yönde, anlamlı $(\mathrm{p}<0,05)$ ve orta düzeyde bir ilişki görülmüştür.

- Konuyu somutlaştırarak anlatmak ile güdüleme ve dikkat toplama arasında anlamlı $(p<0,05)$, orta düzeyde ve pozitif bir korelasyon saptanmıştır.

- Öğrenci ile pozitif ilişki kurmak alt boyutu ile güdüleme, derse odaklanma, dikkat toplama ve olumlu tutum arasında anlamlı $(\mathrm{p}<0,05)$, orta düzeyde ve pozitif bir ilişki görülmüştür.

\section{Tartışma, Sonuç ve Öneriler}

Bu bölümde araştırmadan elde edilen bulgular alan yazında konuyla ilgili yapılan çalışmalar 1şığında tartışılmış ve önerilere yer verilmiştir. Öğretmenlerin öğrenme güçlügü yaşayan öğrencilere yönelik yeterlikleri, öz yeterlik kaynakları ve pozitif öğretmenlik becerileri arasındaki ilişkinin incelendiği bu çalışmada öğretmenlerde dikkat toplama, olumlu tutum ve derste akış yaşatma becerileri arttıkça performans başarılarının da arttığı sonucuna ulaşılmıştır. Yapılan çalışmalar, öğretmenlerin içsel motivasyonları arttıkça başarılarının da arttığını göstermektedir. İç motivasyonların (sorumluluk duygusu, derse karşı olumlu tutum ve başarma isteği, öğretmenlik mesleğinden hoşlanma gibi) başarı ile doğru orantılı olduğu ifade edilmiştir (Ada, Akan, Ayık, Yıldırım ve Yalçın, 2013; Lin, McKeachie ve Kim, 2003; Yazıc1, 2009). Bu sonuçlar çalışmadan elde edilen bulguyu destekler niteliktedir.

Çalışmadan elde edilen ikinci bulgu ise dışa dönük kişilik özelliklerine sahip olan öğretmenlerin derse odaklanma ve dikkat toplama becerilerinde daha yeterli olduklarıdır. Roberts ve arkadaşları (2001) da yaptıkları çalışmada yeterlik sahibi bireylerin her konuda yüksek gayret gösterme yatkınlığına sahip olduğu sonucuna ulaşmışlardır. Ayrıca kendi öz yeterliğinin farkında ve öz yeterliliklerini geliştirme sürecinde karşılaştığı güçlüklere rağmen motivasyonlarının düşmediği çalışmadan elde edilen bulgulardandır. Bunun, yüksek öz yeterliğe sahip insanların güçlü inançlara sahip olmasından kaynaklandığı söylenebilir. Chiang, Hsu ve Shih (2015), yaptıkları çalışmada dışa dönük kişilik özelliklerine sahip bireylerin performanslarında bilgi alışverişi etkisinin güçlendiğini ve dolaylı olarak yaratıcılık becerilerinin de olumlu şekilde etkilendiğini ifade etmişlerdir. Roberts, Harlin ve Briers (2007), öğretmenler üzerinde yapmış oldukları çalışmada dışa dönük öğretmen tutumunun öğretmenin sınıf yönetimini, öğrenci katılımını, öğretim stratejilerini olumlu bir şekilde etkilediği sonucuna ulaşmışlardır. Öğretmenlerin öz yeterlik inancı ile öğretecekleri ve öğrencileri de hayata hazırlamak adına iyi bir şekilde eğitip, adaptasyon süreci göz önünde bulundurulduğunda öğretmenlerin öz yeterlik konusuna gereken önemi vermeleri gerektiği görülmektedir (Robers ve ark., 2001). Çalışma grubunu öğretim elemanlarının oluşturduğu ve öğretim elemanlarının kişilik yapılarının öğrencilerin İngilizce eğitim programındaki motivasyonlarına etkisinin incelenmesinin amaçlandığı çalışmada dışa dönük, algılayıcı ve 
dikkat gibi kişilik yapılarına sahip öğretim elemanlarının öğrencilerin öğrenme motivasyonlarını olumlu şekilde etkilediği belirlenmiştir (Sudarsi, Hamra ve Mahmud, 2016). 19 öğretmenin 5 yıllık boylamsal araştırma ile incelendiği çalışmada öğretmenlerin kişilik özelliklerinin öğretme sürecine etkisi incelenmiştir. Bu beş yıllık araştırma sonucunda olumlu kişiliğe sahip öğretmenlerin profesyonellik seviyelerinin yüksek olduğu, öğretim etkinliğini arttırdıkları, aynı zamanda öğrencilerin duygusal dengesine katkıda bulunarak akademik başarıları ile motivasyonlarını artırdıkları belirlenmiştir (Idris, Johari ve Bakar, 2018). Alan yazında yer alan çalışmaların bulgumuzu desteklediği görülmektedir.

Çalışmada konuyu somutlaştırarak anlatan öğretmenlerin öğrencileri güdüleme ve dikkatini toplama hususunda daha yeterli oldukları saptanmıştır. Dersi etkili ve verimli bir hale getirmek için farklı görseller, materyaller ve öğretim yöntemleri kullanan öğretmenlerin öğrencileri derse karşı motive ettikleri ve ders süresince dikkatlerini toplamayı sağladıkları belirlenmiştir. Satsangi, Bouck, Taber-Doughty, Bofferding ve Roberts (2016)'nn matematik öğrenme güçlüğü (diskalkuli) yaşayan 3 öğrenci ile deneysel olarak yaptıkları araştırmada öğrencilere sanal ve somut öğrenme deneyimleri sunulmuş eğitim süreci sonucunda somut öğrenme deneyimi yaşayan üç öğrenciden ikisinin aldığ1 puanların daha yüksek olduğu belirlenmiştir. Benzer bir bulgu olarak Agrawal ve Morin (2016) yaptıkları çalışmada, matematik öğrenme güçlüğü yaşayan yani sınıf içerisinde farklı matematik kavramlarının hem kavramsal hem de işlemsel bilgisi ile ilgili zorluklar yaşayan öğrencilere sunulan somut öğrenme deneyimlerinin öğrencileri konuya güdülediği ve bu güçlüğü kolaylaştırdığ1 sonucuna ulaşmışlardır. Duygusal ve davranışsal problemi olan öğrencilerin öğrenimi sırasında kullanılan somut öğretim yöntemlerinin de öğrencilerinin öğrenme çıktısı üzerinde olumlu etki yaptığı araştırmalar sonucunda ortaya çıkan sonuçlardandır (Mulcahy ve Krezmien, 2009; Peltier ve Vannest, 2018; Ralston, Benner, Tsai, Riccomini ve Nelson, 2014). Somut öğretim yöntemlerinin öğrenciler üzerindeki etkisinin belirlenmeye çalışıldığ1 araştırmalar incelendiğinde çalışmaların genellikle soyutluğun daha yoğun olduğu matematik öğretimi konusunda ve öğrenme sürecinde güçlükler yaşayan öğrenciler ile yapıldığ 1 görülmektedir. Ayrıca bu çalışmalardan elde edilen bulgular araştırma sonucunda ulaşılan bulguyu desteklemektedir (Bouck, Park ve Nickell; 2017; Bouck, Satsangi ve Park, 2018; Flores, Hinton, Strozier ve Terry, 2014; Flores, 2010; Strickland ve Maccini, 2013).

$\mathrm{Bu}$ çalışma da, öğrenme güçlüğü yaşayan öğrencilere yönelik öğretmen yeterliliğinden; dikkate alma, güdülenme, derse odaklanma, dikkat toplama ve olumlu tutumları arttıkça derse akış yaşatma becerilerinin de artığı görülmüştür. Spitek ve arkadaşları (1998) öğretmenlerin öğrencileri teşvik etmelerinin, geri bildirimler sunmalarının, anlatılan konuyu daha ilgi çekici hale getirip farklı eğitsel metodlar kullanmalarının, geri bildirimde bulunmanın dersin verimliliğini artırdığını belirtmişlerdir. Araştırma sonuçları; öğrencilerin öğretmenleri ile etkileşimde olduğu eğitim süreçlerinin akademik başarıda önemli bir etken olduğunu göstermektedir (Bandura, 1997; Chermers, Hu ve Garcia, 2001; Pajares, 1997; Robbins, Lauver, Le, Davis, Langley ve Carlstrom, 2004; Zajocava, Lynch ve Espenshade, 2005). Bahar (2019), çalışmasında öz-yeterlik inançlarının akademik başarıyı artırdığı ve akademik başarının sağlanmasında önemli bir yol gösterici olduğunu belirtmiştir. Yine aynı çalışmada öğrencilerin sınıfta sordukları soruya cevap verme, anlamadığı konunun tekrar anlatılmasını talep etme, okunan veya sınıfta ortaya konan fikirlerin çoğunu anlama gibi becerileri akademik başarı ile ilişkili bulunmuştur. Özel öğrenme güçlüğü çeken öğrencilerin gözlemlenmesi ve tutulan saha notları ile gerçekleşen çalışmada bu öğrencilerin özgüven problemi yaşadıklarına vurgu yapılmış ve öğrencilerin özgüvenlerinin güçlendirilmesinin 


\section{Öğretmenlerin Öğrenme Güçlüğü Yaşayan Öğrencilere Yönelik Yeterlikleri, Öz Yeterlik Kaynakları ve Pozitif Öğretmenlik Becerileri Arasındaki İlişki}

öğrenim becerilerini de arttıracağı sonucuna ulaşılmıştır (Görgün ve Melekoğlu, 2019). Öğretmenlerin duygusal beceri, empati düzeyleri ve hipotez kurma yetenekleri ile öz yeterlilikleri arasındaki ilişkinin incelenmesinin amaçlandığı çalışma sonucunda öz yeterlik inançlarının duygusal beceri, hipotez kurma ve empatiye aracılık ettiği belirlenmiştir. Yani öğretmenlerin öz yeterlik inançlarının doğrudan ve dolaylı olarak duygusal beceri, hipotez kurma ve empatiye aracılık ettiği sonucuna ulaşılmıştır (Hen ve Goroshit, 2016).

Aynı zamanda, Korkut ve arkadaşlarının (2016) konuyla ilgili çalışmalarında, öğrenme güçlüğü yaşayan bireylerin eğitimin her kademesinde var olduğu ve birçok öğretmenin bu tarz öğrencilerle karşılaşma durumunda olması öğrenme güçlüğü yaşayan öğrenciler konusunda öğretmen yeterliklerinin belirlenip, gerekli önlemlerin alınmasını zorunlu hale getirdiği belirlenmiştir. Bu sonuç yapılan çalışmanın önemini göstermektedir. Çalışmadan elde edilen sonuçlar doğrultusunda;

Öğrenme güçlüğü yaşayan çocuklarda somut öğrenme deneyimlerine dayalı eğitimin çocukların gelişimine etkisinin araştırıldığ 1 boylamsal desende çalışmalar yapılabilir. Eğitim fakültesinde öğrenim gören tüm branşlardaki öğretmen adaylarının müfredatına öğrenme güçlüğü ile ilgili farkındalıklarının artması adına dersler konulabilir. Sınıflarında öğrenme güçlüğü yaşayan öğrencilerin tespiti ve eğitimi için bilgi düzeylerinin ve yeterliliklerinin arttırılması için öğretmenlere bu konu ile ilgili hizmet içi eğitim verilebilir.

\section{Kaynakça}

Albion, P. R. (1999). Self-efficacy beliefs as an indicator of teachers' preparedness for teaching with technology. In J. D. Price \& J. Willis \& D. A. Willis \& M. Jost \& S.

Ada, Ş., Akan, D., Ayık, A., Yıldırım, İ. ve Yalçın, S. (2014). Öğretmenlerin Motivasyon Etkenleri. Atatürk Üniversitesi Sosyal Bilimler Enstitüsü Dergisi, 17 (3), 151-166.

Agrawal, J., \& Morin, L. L. (2016). Evidence-based practices: Applications of concrete representational abstract framework across math concepts for students with mathematics disabilities. Learning Disabilities Research \& Practice, 31(1), 34-44.

Aral, N., \& Gürsoy, F. (2009). Özel eğitim gerektiren çocuklar ve özel eğitime giriş. İstanbul: Morpa Yayınları.

Boger-Mehall (Eds.), Technology and teacher education annual 1999 (s. 1602- 1608). Charlottesville, VA: Association for the Advancement of Computing in Education.

Bandura, A.(1989a). Regulation of cognitive processes through perceivedself-efficacy. Developmental Psychology 25(5), 729-735.

Bandura, A. (1993). Perceived self-efficacy in cognitive development and functioning. Educational Psychologist, 28(2), 117-148.

Bandura, A. (1994). Self -efficacy. In V.S. Ramachaudran (Ed.),Encyhopedia of human behavior (Vol. 4, pp. 71-81)

Bandura, A. (1997). Self-efficacy: The exercise of control. New York: Freeman.

Brownell, M. T., Pajares, F. (1999). Teacher Efficacy and Perceived Success in Mainstreaming Students with Learning and Behavior Problems. Teacher Education and Special Education 22(3), 154-64. 
Bahar, H. H. (2019). Sınıf öğretmen adaylarında akademik öz-yeterlik algısının akademik başarıyı yordama gücü. İlköğretim Online, 18(1).

Bandura, A. (1997). Self-efficacy: Toward a unifying theory of behavioral change. Psychological Review, 84(2), 191-215.

Bouck, E., Park, J., \& Nickell, B. (2017). Using the concrete-representational-abstract approach to support students with intellectual disability to solve change-making problems. Research in developmental disabilities, 60, 24-36.

Bouck, E. C., Satsangi, R., \& Park, J. (2018). The concrete-representational-abstract approach for students with learning disabilities: An evidence-based practice synthesis. Remedial and Special Education, 39(4), 211-228.

Chiang, Y. H., Hsu, C. C., \& Shih, H. A. (2015). Experienced high performance work system, extroversion personality, and creativity performance. Asia Pacific Journal of Management, 32(2), 531-549.

Cortiella, C., \& Horowitz, S. H. (2014). The state of learning disabilities: Facts, trends and emerging issues. New York: National Center for Learning Disabilities.

Çapa-Aydın, Y., Uzuntiryaki-Kondakçı, E., Temli, Y. \& Tarkın, A. (2013). Özyeterlik kaynakları ölçeğinin Türkçe'ye uyarlanması. İlköğretim Online, 12(3), 749-758.

Demirtaşlı, Ç. N. (7 Eylül, 2007). CİTO Türkiye Öğrenci İzleme Sistemi Sosyal Bilgiler Alanı. CITO-Türkiye 1.Konferans Bildirileri, 40-47, ODTÜ, Ankara

DSM-V (2013). Diagnostical and statistical manual of mental disorders. Fifth Edition. American Psychiatric Association.

Enderlin-Lampe, S. (2002). Empowerment: Teacher perceptions, aspirations, and efficacy. Journal of Instructional Psychology, September, 1-8.

Eryılmaz, A. (2014). Perceived Personality Traits and Types of Teachers and Their Relationship to the Subjective Well-being and Academic Achievements of Adolescents. Educational Sciences: Theory \& Practice 14(6), 2049-2062.

Eryılmaz, A. (2017). Initial Development and Validation of the Positive Teacher Scale. Journal of Positive Psychology \& Wellbeing 1(1), 10-21

Eryılmaz, A. \& Bek, H . (2018). “Pozitif Öğretmen Ölçeği” Öğretmen Formunun Geliştirilmesi. Kastamonu Eğitim Dergisi, 26(4) , 1297-1306. DOI: 10.24106/kefdergi.369825

Flores, M. M., Hinton, V. M., Strozier, S. D., \& Terry, S. L. (2014). Using the concreterepresentational-abstract sequence and the strategic instruction model to teach computation to students with autism spectrum disorders and developmental disabilities. Education and Training in Autism and Developmental Disabilities, 547-554.

Flores, M. M. (2010). Using the concrete-representational-abstract sequence to teach subtraction with regrouping to students at risk for failure. Remedial and Special Education, 31(3), 195-207.

Flanagan, D. P., Ortiz, S. O. \& Alfonso, V. C. (2011). Essentials of Cross-Battery Assessment. Kaufman, A. S., and Kaufman, N. L. (Eds.), Expert advice on identifying specific learning disabilities (3th ed.). Canada: John Wiley and Sons, Inc. 


\section{Öğretmenlerin Öğrenme Güçlüğü Yaşayan Öğrencilere Yönelik Yeterlikleri, Öz Yeterlik Kaynakları ve Pozitif Öğretmenlik Becerileri Arasındaki İlişki}

Fletcher, J. M., Lyon, G. R., Fuchs, L. S. \& Barnes, M. A. (2007). Learning disabilities: from identification to intervention. New York: Guilford Press.

Galpin, V. C., Senders, I., Turner, H. \& Venter, B. (2003). Gender and educational background and their effect on computer self- efficacy and perceptions. Technical Report TR-Wits-CS2003-0, School of Computer Science, University of the Witwatersrand IDEA, (2004) Individuals with Disabilities Education Improvement Act of Pub.L.No.108-446.

Görgün, B. \& Melekoğlu, M. A. (2019). Özel Öğrenme Güçlüğü Olan Öğrencilerin Akıc1 Okuma ve Okuduğunu Anlama Becerilerini Geliştirmeye Yönelik Okuma Destek Programının Geliştirilmesi. İlköğretim Online, 18(2).

Grieve, A. M. (2010). Exploring the characteristics of 'teachers for excellence': teachers' own perceptions. European Journal of Teacher Education, 33(3), 265-277.

Grünke, M., \& Cavendish, W. M. (2016). Learning disabilities around the globe: Making sense of the heterogeneity of the different viewpoints. Learning Disabilities: A Contemporary Journal, 14(1), 1-8.

Helterbran, V. R. (2008). Professionalism: Teachers taking the reins. The Clearing House: a journal of educational strategies, issues and ideas, 81(3), 123-127.

Hen, M., \& Goroshit, M. (2016). Social-emotional competencies among teachers: An examination of interrelationships. Cogent Education, 3(1), 1151996.

Idris, Z., Johari, K. S. K., \& Bakar, A. Y. A. (2018). Meta-Synthesis Study: Positive Effects on Positive Personality of Teachers in Teaching Profession. International Journal of Academic Research in Business and Social Sciences, 8(1), 740-749.

İşeri, E. \& Akın-Sarı, B. (2011). Çocukta bilişsel gelişim ve bozukluklar: Zeka geriliği ve öğrenme bozuklukları. S. Karakaş. (Ed.). Kognitif Nörobilimler (s. 489-510). Ankara: MN Medikal \& Nobel Tip Kitap Sarayı.

Jena, S. P. K. (2013). Learning disability: Teory to practice. New Delphy: Sage Publicatio

Keskin, İ., Korkut, A. \& Can, S. (2016). Öğrenme güçlüğü yaşayan öğrencilere yönelik öğretmen yeterlilikleri ölçeğinin geliştirilmesi. Amasya Üniversitesi Ĕ̆itim Fakültesi Dergisi, 5(1), 133-155. doi:10.17539/aej.43261.

Kieffer, K. M., \& Henson, R. K. (2000). Development and Validation of the Sources of SelfEfficacy Inventory (SOSI): Exploring a New Measure of Teacher Efficacy.

Korkut, A., Keskin, İ., \& Can, S. (2016). Öğrenme güçlüğü yaşayan öğrencilere yönelik öğretmen yeterlilikleri ölçeğinin geliştirilmesi. Amasya Üniversitesi Ĕ̆itim Fakültesi Dergisi, 5(1), 133-155.

Lin, Y. G., McKeachie, W. J., \& Kim, Y. C. (2003). College student intrinsic and/or extrinsic motivation and learning. Learning and individual differences, 13(3), 251-258.

Mc Leod, Terry. (1993). "Social - Behavioral Characteristics" Learning Disabilities Best Practices for Proffessionals (Ed. William Bender). USA: Butter-Heinneman,.

Melekoğlu, M. A. (2017). Özel öğrenme güçlüğünün nedenleri ve özellikleri. Macid Ayhan Melekoğlu ve Uğur Sak (Ed.). Öğrenme güçlüğü ve özel yetenek (s. 24-53). Ankara: Pegem. 
Montalvo, G. P., Mansfield, E. A., \& Miller, R. B. (2007). Liking or disliking the teacher: Student motivation, engagement and achievement. Evaluation \& Research in Education, 20(3), 144158.

Morrison, J. (2016). DSM-5'i kolaylaştıran ‘Klinisyenler için tanı rehberi'. Muzaffer Şahin (Çev Ed.). Ankara: Nobel.

Mulcahy, C. A., \& Krezmien, M. P. (2009). Effects of a contextualized instructional package on the mathematics performance of secondary students with EBD. Behavioral Disorders, 34(3), 136-150.

Olkun, S., Akkurt-Denizli, Z. \& Göçer-Şahin, S. (2015). Öğrencilerin diskalkuliye yatkınlıklarının belirlenmesinde nokta sayılama ve sayısal karşılaştırma becerileri. Turkish International Journal of Special Education and Guidance E Counseling, 3(2), 62-71.

Özbağır, T. (2019). Ö̆̆retmenlerde psikolojik dayanıklılı̆̆ı duygusal zekayla, pozitif öğretmen özellikleriyle ve demografik değişkenlerle ilişkisi. Yayınlanmamış yüksek lisans tezi, Yıldız teknik üniversitesi, İstanbul.

Pajares, F. (1996). Self-efficacy beliefs in academic settings. Review of Educational Research, $66,543-578$.

Pesovaa, Sivevskab \& Runcevac (2014). Early Intervention and Prevention of Students with Specific Learning Disabilities. Social and Behavioral Sciences 149, 701-708.

Raudenbush, S.W., Rowan, B. \& Cheong, Y.F. (1992). Contextual effects on the self- perceived efficacy of high school teachers. Sociology of Education, 65 (2), 150-167.

Satsangi, R., Bouck, E. C., Taber-Doughty, T., Bofferding, L., \& Roberts, C. A. (2016). Comparing the effectiveness of virtual and concrete manipulatives to teach algebra to secondary students with learning disabilities. Learning Disability Quarterly, 39(4), 240-253.

Strickland, T. K., \& Maccini, P. (2013). The effects of the concrete-representational-abstract integration strategy on the ability of students with learning disabilities to multiply linear expressions within area problems. Remedial and Special Education, 34(3), 142-153.

Sudarsi, E. T., Hamra, A., \& Mahmud, M. (2016). The Effects of Lecturers' Personality on Students' Learning Motivation. Elt Worldwide, 3(2), 188-203.

Şahin, F. \& Çakır, R. (2018). Çoklu Ortam Materyallerinin Okuma-Yazma Güçlügü Çeken Öğrencilerin Okuma-Yazma Becerileri Üzerinde Etkisi. Öğretim Teknolojileri E Öğretmen Ĕ̈itimi Dergisi, 7(2), 75-90.

Tekbıyık, A. (2014). İlişkisel tarama (M. Metin, ed.). Kuramdan uygulamaya eğitimde bilimsel araştırma yöntemleri (99-114). Ankara: Pegem Akademi Yayıncılık.

Thibodeau, G. P., \& Hillman, S. J. (2003). In retrospect: teachers who made a difference from the perspective of preservice and experienced teachers. Education, 124(1), 169-180.

Thomas, D. \& Woods, H. (2003). Working with people with learning disabilities: Theory and practice. London: Jessica Kingsley Publishers

U.S. Department of Education. (2014). In Proceedings of the 36th annual report to congress on the implementation of the individuals with disabilities education act, 2014. Washington, D.C.: Office of Special Education and Rehabilitative Services. 
Peltier, C., \& Vannest, K. J. (2018). Using the concrete representational abstract (CRA) instructional framework for mathematics with students with emotional and behavioral disorders. Preventing School Failure: Alternative Education for Children and Youth, 62(2), 73-82.

Ralston, N. C., Benner, G. J., Tsai, S. F., Riccomini, P. J., \& Nelson, J. R. (2014). Mathematics instruction for students with emotional and behavioral disorders: A best-evidence synthesis. Preventing School Failure: Alternative Education for Children and Youth, 58(1), 1-16.

Roberts, G., Harlin, J., \& Briers, G. (2007). The Relationship Between Teaching Efficacy And Personality Type Of Cooperating Teachers. Journal Of Agricultural Education, 48(4), 55-66.

Roberts, J.K., Henson, R.K., Tharp, B.Z. ve Moreno, N. (2001). An Examination of Change In Teacher Self-Efficacy Beliefs In Science Education Based On The Duration of In-Service Activities, Journal of Science Teacher Education, 12(3): 199-213.

Yavuzer, H. (2000). Okul Çă̆ı Çocŭ̆u. İstanbul: Remzi Kitabevi.

Yazıcı, H. (2009). “Öğretmenlik Mesleği, Motivasyon Kaynakları ve Temel Tutumlar: Kuramsal Bir Bakış". Kastamonu Eğiti Dergisi, 17(1), 33-46.

Zuriff, G.E. (2000). Extra examination time for students with learning disabilities: An examination of the maximum potential thesis. Applied Measurement in Education, 13(1), 99117. 